\title{
Use of coliphages to evaluate water treatment processes and determine faecal contamination origin of source waters
}

\author{
A. Okeyo $\cdot$ M. Coetzee $\cdot$ M. N. B. Momba
}

Received: 17 May 2011/Revised: 4 March 2012/Accepted: 28 August 2012/Published online: 17 May 2013

(C) Islamic Azad University (IAU) 2013

\begin{abstract}
Viral indicators were used to evaluate the effectiveness of water treatment processes and to determine the source of faecal pollution with a view to promote water source management. Water samples were collected from three critical points of the Temba, Klipdrift and Wallmansthal water treatment plants (raw water, settled water and filtered water). The viral indicator concentrations and selected physicochemical parameters were measured using standard methods. Random water samples were subjected to real-time polymerase chain reaction analyses. Subsequent to filtration, the removal efficiency of the three Waterworks was recorded as follows: 93.2, 96.1 and $95.7 \%$ for somatic coliphages, respectively; and 69.4 and $68.4 \%$ FRNA coliphages for Temba and Klipdrift. There was a notable $50 \%$ reappearance of FRNA coliphages in filtered water samples from Wallmansthal. Positive correlations were observed between the physicochemical parameters and somatic coliphages, with the exception of the $\mathrm{pH}$ and the temperature in Wallmansthal. Both turbidity and temperature indicated positive correlations with FRNA counts from Temba and Klipdrift. Negative correlations were observed between all the physicochemical parameters and FRNA counts from Wallmansthal. The real-time polymerase chain reaction analyses revealed the persistence of GA genotype FRNA (Group II, which is of human faecal origin) in all the water samples. The MS2 genotype (Group I) and Q $\beta$ genotype (Group III) FRNA, which are of animal origin, were detected only in the raw water from Temba. Efforts should be focused on the protection of
\end{abstract}

A. Okeyo $\cdot$ M. Coetzee $\cdot$ M. N. B. Momba $(\bowtie)$ Department of Environmental, Water and Earth Sciences, Tshwane University of Technology, Arcadia Campus, Private Bag X680, Pretoria 0001, South Africa e-mail: mombamnb@tut.ac.za water sources and the optimisation of treatment processes in order to prevent viral persistence during water treatment.

Keywords Viral indicators · Treatment efficiency · Faecal pollution . Water source

\section{Introduction}

The application of a comprehensive risk assessment and risk management scheme is of paramount importance in ensuring the safety of a drinking water supply. Such a scheme should encompass all the important steps during the treatment (screening, coagulation, flocculation, sedimentation, clarification and filtration) and the distribution (at the point of consumption) of drinking water. Over time, water source management has been noted as being the best initial approach for ensuring the safety of the water supply before the drinking water undergoes any treatment that could result in the removal of contaminants. According to the World Health Organization (WHO) guidelines for drinking water quality, such approaches are known as water safety plans (WHO 2006). It has been reported that by decreasing the contamination of source water, (1) the amount of treatment required is reduced, which lowers the probability of the production of by-products and (2) the rate of water-related outbreaks is curbed with the reduction in the source pathogen load (WHO 2004a, 2006).

Bacteriological indicators are primarily used for water source management; however, it has been noted that they do not provide protection against viruses, which are more persistent in aquatic environments and resistant to treatment (Sundram et al. 2002; Fong and Lipp 2005). Diseases caused by human enteric viruses are predominantly associated with the ingestion of human-derived waste because 
of their host-specificity (Sundram et al. 2002). The use of somatic coliphages and F-specific RNA(FRNA) coliphages as candidate alternative indicators of viral pathogens has been proposed (Debartolomeis and Cabelli 1991; Havelaar et al. 1993).

Studies have reported somatic coliphages as a heterogenous group of viruses present in faecal sources; thus, the appearance of these viruses in water means that they can serve as general faecal pollution indicators and may also indicate the concurrent presence of other enteric viruses (Havelaar et al. 1990; Calci et al. 1998). FRNA-specific coliphages have been used to discriminate between faecal sources by typing them into four subgroups. These subgroups have been reported to be associated with human (Group II-GA and III-Q $\beta$ ) or animal faecal contamination (Group I-MS-2 and IV-SP) (Sundram et al. 2002; Dryden et al. 2006).

Various methods can be used to determine whether the source of water pollution is of human or non-human origin. These include conventional microbiological and molecular techniques. Studies have indicated that more than 100 types of human pathogenic viruses may be present in faecally polluted water, but they are undetected by the currently available conventional methods (Havelaar et al. 1993). It has been pointed out that it is unusual for these conventional methods to consistently recover more than 50-60\% of the viruses that are present in a water sample (Lee and Jeong 2004). The importance of the use of molecular methods for the management of the viral quality of drinking water over time has therefore become apparent. Both culturable and non-culturable viruses can be detected at very low levels using molecular-based methods that target specific DNA or RNA sequences in the genetic information of a virus. Virus assay, using polymerase chain reaction (PCR), for instance, can target individual viruses and viral groups of relevance in a particular sample (Greening et al. 2002). Furthermore, studies and advances in real-time PCR (RT-PCR) have rendered these methods to be both rapid and quantitative (Lewis et al. 2000).

This study was aimed at using coliphages to evaluate the effectiveness of the water treatment processes prior to chlorination in the Temba, Klipdrift and Wallmansthal water treatment plants (WTPs) and to determine the probable origin of faecal contamination of source waters with a view to establishing the sustainable management of these water treatment plants. Our intention was to identify any potential process failures that might result in a decline of the performance of these plants in the removal of viral indicators. Also considered were physical and chemical parameters such as $\mathrm{pH}$, temperature and turbidity. These plants were chosen because they supply the surrounding semi-urban areas, which, according to the literature, often face water quality problems. The study was conducted in peri-urban areas of the Gauteng Province-South Africa, between September 2007 and April 2008.

\section{Materials and methods}

Description of the drinking water processes, water treatment plants and sample collection

Temba, Klipdrift and Wallmansthal WTPs serve the peri-urban areas situated in the Gauteng Province. This province, also referred to as the "place of gold", is the smallest (17 000 square kilometres), wealthiest and most densely populated (approximately 9.8 million people) province in South Africa. It is situated in the north-eastern part of the country and is landlocked. The province is bordered by Limpopo in the north, Mpumalanga in the east, the Free State in the south and the North West Province in the west. It mainly comprises three urban areas, namely Pretoria, Johannesburg and the southern VereenigingVanderbijlpark industrial complex. The Gauteng Province consists of three metropolitan municipalities (Johannesburg, Tshwane and Ekurhuleni) and three district municipalities, which are further divided into eight local municipalities (the Nokeng, Kungwini, Lesedi, Midvaal, Emfuleni, Westonaria, Randfontein and Mogale local municipalities).

The initial operating capacity of the Temba Plant was $30 \mathrm{~mL} /$ day, which has been increased, as a result of growing demand, to $60 \mathrm{~mL} /$ day, with five distinctive divisions. The expansion has alleviated the water shortage problem that had previously occurred in the Moretele water supply scheme. The Klipdrift WTP was extended and upgraded by the Department of Water Affairs and Forestry in 2004. It has an operational capacity of $18 \mathrm{~mL} /$ day. The Wallmansthal WTP has an operational capacity of $12 \mathrm{~mL} /$ day. Figure 1 summarises the general description and modes of treatment of the Temba, Klipdrift and Wallmansthal WTPs.

Water samples ( $1 \mathrm{~L})$ were collected from the raw water catchment, before filtration (settled) and after filtration points, and preserved according to the standard procedure (APHA 2001). The effectiveness of the sedimentation and filtration processes for the removal of indicator coliphages (somatic and FRNA) was then assessed. To determine the origin of faecal contamination of water sources using molecular techniques, eight water samples were selected randomly from each pre-treatment process during the 5 months of the study period.

Physicochemical analysis

Turbidity (EUTECH instruments-TN 100), pH and temperature (EUTECH instruments-cyberscan PC 300) metres were used for on-site physicochemical analysis of the water samples according to standard methods (APHA 2001). 


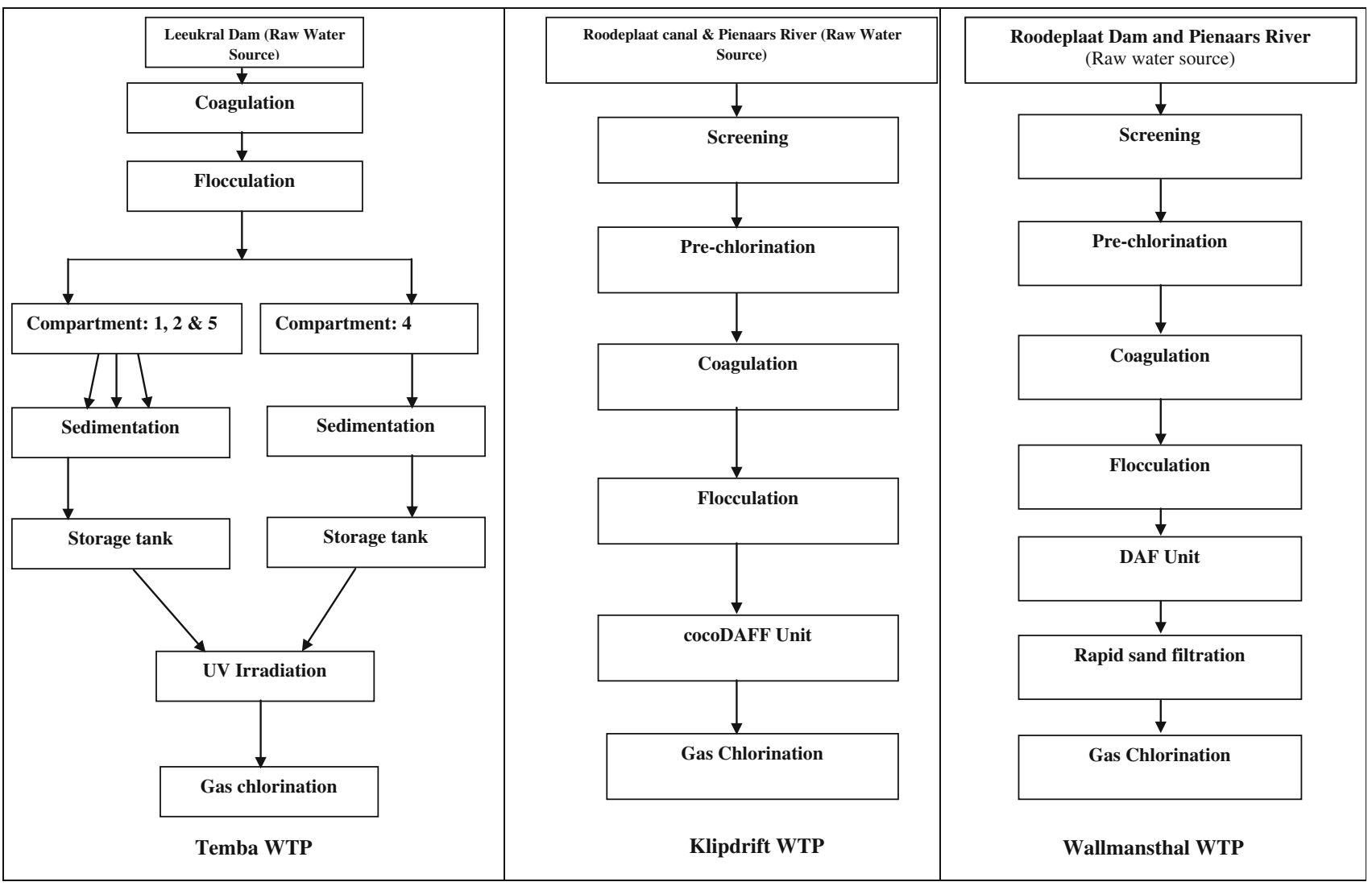

Fig. 1 Schematic diagram of drinking water processes. WTP water treatment plant, cocoDAFF counter current dissolved air flotation filtration, dissolved air flotation unit: DAF

Culture-based detection and enumeration of somatic and F-specific RNA coliphages

Enumeration of somatic coliphages and FRNA coliphages was carried out on double-agar-layer plaque assay using Escherichia coli strain C (ATCC 13706) nalidixic acid-resistant mutant WG5 and Salmonella typhimurium WG 49 nalidixic acid-resistant mutant as hosts. The preparation of inoculum cultures, the detection and the enumeration of these viral indicators were performed as described elsewhere (ISO 1995, 1998).

Genotyping of F-specific RNA coliphages

Positive FRNA coliphage strains Group I-MS2 (DSM No.: 13767), Group II-GA (DSM No.: 5549) and Group III-QB (DSM No.: 13768) were supplied by DSMZGermany (Deutsche Sammlung von Mikroorganismen und Zellkulturen $\mathrm{GmbH}$ ). Coliphage propagation was conducted according to the manufacturer's instructions with a slight modification. Briefly, the concentrated phage suspensions were used to make serial dilutions of 1:2 using the medium specified by the manufacturer for each strain.
These were then stored in Eppendorf tubes containing glycerol at $-20{ }^{\circ} \mathrm{C}$ until use (Fig. 2).

Oligonucleotide primers

Table 1 displays the sequences of primers for the FRNA coliphages used in this study. They have been reported as being specific for the three strains that were the focus of this study (Ogorzaly and Gantzer 2006).

\section{Extraction of RNA}

Extraction of RNA from the samples and positive controls was conducted by means of an RNEasy Viral RNA extraction kit (RNEasy, Qiagen, Germany). The extraction was performed according to the manufacturer's instructions. A DNAse step was included in the extraction to remove the contaminating DNA from RNA preparations.

\section{RT-PCR FRNA identification}

The protocol present in the iScript one-step RT-PCR Kit with SYBR green (Biorad, SA) was used for the direct 

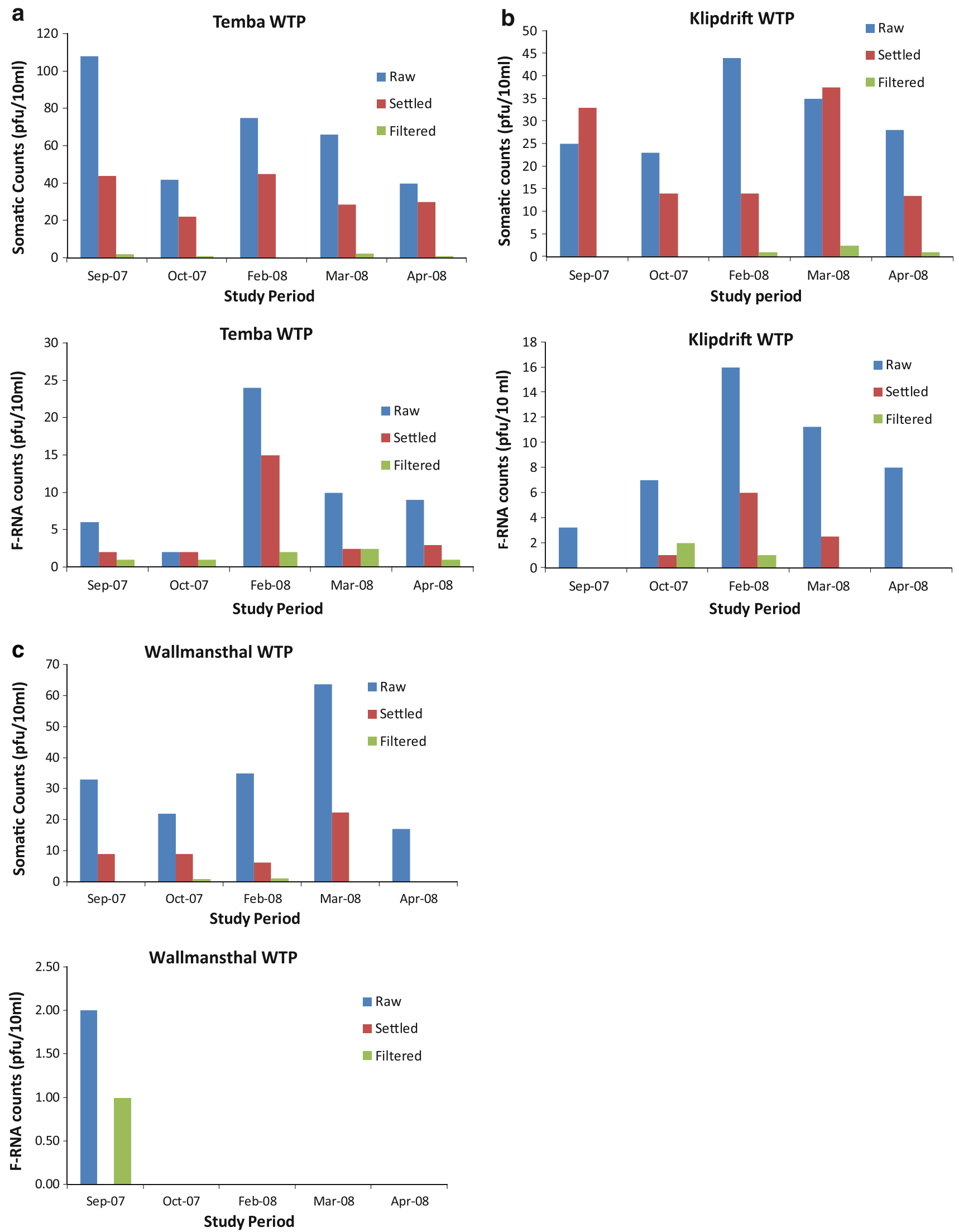

Fig. 2 Performance of the different drinking water treatment plants in the removal of the somatic and FRNA-specific coliphages (average pfu/10 mL) during the study period from 3 September 2007 to 29 April 2008 
Table 1 Sequences of designed primers for FRNA-specific coliphages (Ogorzaly and Gantzer 2006)

\begin{tabular}{llll}
\hline Coliphage & Primer & Sequence $\left(5^{\prime}-3^{\prime}\right)$ & Source \\
\hline Genogroup I-MS2 (NC_00147) & G1For & TCAGTGGTCCATACCTTAGATGC & Group 1-Predominantly animal faecal contamination \\
& G1Rev & ACCCCGTTAGCGAAGTTGCT & \\
Genogroup II-GA (NC_001-426.1) & G2For & TGCAAACCTAACTCGGAATGG & Group 2-Predominantly human faecal contamination \\
& G2Rev & AGGAGAGAACGCAGGCCTCTA & \\
Genogroup III-QB (AY099114.1) & G3For & CCGCGTGGGGTAAATCC & Group 3-Predominantly human faecal contamination \\
& G3Rev & TTCTTACGATTGCGAGAAGGCT & \\
\hline
\end{tabular}

conversion of RNA to cDNA and the RT-PCR run. The $\mathrm{PCR}$ was carried out in $25 \mu \mathrm{L}$ reaction mixtures containing $12.5 \mu \mathrm{L} 2 \times \mathrm{SYBR}$ green $\mathrm{RT}$-PCR reaction mix, $0.5 \mu \mathrm{L}$ of each primer, $8 \mu \mathrm{L}$ of nuclease-free water, $3 \mu \mathrm{L}$ of the RNA template and $0.5 \mu \mathrm{L}$ iScript reverse transcriptase for onestep RT-PCR. The complete reaction mixture was heat activated at $50{ }^{\circ} \mathrm{C}$ for $10 \mathrm{~min}$ for the synthesis of cDNA and at $95{ }^{\circ} \mathrm{C}$ for $5 \mathrm{~min}$ for the inactivation of the reverse transcriptase. This was followed by 46 cycles of PCR at $95{ }^{\circ} \mathrm{C}$ for $10 \mathrm{~s}$ and at $57{ }^{\circ} \mathrm{C}$ for $30 \mathrm{~s}$. Data were collected after every cycle, and the results were analysed with the MJ Opticon Monitor Analysis Software (BioRad, SA).

\section{Statistical analysis}

Multiple correlation analyses were used to determine the relationship between the values of physicochemical parameters ( $\mathrm{pH}, \mathrm{NTU}$ and temperature) and the counts of viral indicators obtained in each water treatment process (somatic and F-RNA coliphages). A two-tailed hypothesis testing procedure was performed to establish the significance of the correlation between these variables. The null hypothesis states that the correlation coefficient is zero (or close enough to be taken as zero). The hypothesis is rejected at the $5 \%$ level if the significance ( $p$ value) is less than 0.05 .

\section{Results and discussion}

Viral indicator monitoring with regard to water quality management is evidently of the utmost importance. The persistence of viral particles in water environments, in comparison with bacteria alone, has rendered viral pathogen monitoring critical in routine water quality control. Somatic and FRNA coliphages can be relied on because they are relatively simple and can be detected rapidly. Moreover, they are always present in the faeces of many warm-blooded animals as indicators of faecal pollution, when compared to bacteria (Grabow 2001). This study was designed to evaluate the general efficiency of sedimentation (after coagulation/flocculation) and filtration processes used prior to the chlorination of the final water in the Temba, Klipdrift and Wallmannsthal WTPs in the removal of viral indicators (somatic and FRNA coliphages) and to determine the source of faecal pollution with a view to water source management.

During water treatment, the removal of viruses occurs through their physical association with other particles in the water. Due to the extremely small sizes of viruses, they are highly unlikely to be removed without this association. Water treatment processes such as coagulation, flocculation, sedimentation and sand filtration result in the physical removal of particles that may be associated with viruses (WHO 2006). Thus, the effectiveness of these processes determines the fate of viral particles and their removal or inactivation (LeChevelier and Au 2004).

Physicochemical characteristics of raw, settled and filtered water samples

The selected physicochemical parameters (turbidity, $\mathrm{pH}$ and temperature) analysed during the study period are commonly used in the general water quality assessment (DWAF 1996; SANS 2006) and are ideal candidates for virus removal and inactivation (Sobsey 1989; Dryden et al. 2006; Lugoli et al. 2009). Table 2 illustrates the selected physicochemical characteristics of the pre-treated water samples collected prior to the chlorination of the final water.

During the study period, the maximum turbidity values $>65$ NTU were recorded in raw water samples collected from Temba and Klipdrift WTPs. However, the average turbidity value of the raw water from the former (39.8 NTU) was higher when compared to those of Klipdrift (18.5 NTU) and Wallmansthal (11.9 NTU) WTPs. In general, there was a decrease in the turbidity values from raw water to filtered water for all the plants, although the average turbidity values in the settled waters at the Temba (6.8 NTU) and Klipdrift WTPs (16.8 NTU) were above the recommended limit of 5 NTU (WHO 2004b). Settled water samples from Klipdrift revealed a higher average turbidity value compared to those of Temba and Wallmansthal (2.8 NTU). For filtered water samples, the average turbidity 
Table 2 Selected physicochemical values recorded from the water treatment plants' (WTPs) pre-chlorination sites during the study period from 3 September 2007 to 29 April $2008(\mathrm{~N}=24)$

\begin{tabular}{|c|c|c|c|c|c|c|c|}
\hline \multirow[t]{2}{*}{ WTP } & \multirow[t]{2}{*}{ Water Type } & \multicolumn{2}{|c|}{ Turbidity (NTU) } & \multicolumn{2}{|l|}{$\mathrm{pH}$} & \multicolumn{2}{|c|}{ Temperature $\left({ }^{\circ} \mathrm{C}\right)$} \\
\hline & & Average & $\operatorname{Max}-\min$ & Average & Max-min & Average & $\operatorname{Max}-\min$ \\
\hline \multirow[t]{3}{*}{ Temba } & Raw water source & $39.8( \pm 16.8)$ & $4.85-66.9$ & $8( \pm 0.3)$ & $7.6-8.69$ & $22.8( \pm 2.5)$ & $18-26.7$ \\
\hline & Sedimentation & $6.8( \pm 6.5)$ & $1.54-34$ & $8.9( \pm 0.5)$ & $7.83-9.5$ & $23.3( \pm 2.8)$ & $18.5-27.8$ \\
\hline & Filtration & $0.4( \pm 0.3)$ & $0.08-1.64$ & $8.8( \pm 0.8)$ & $7.8-9.41$ & $23.9( \pm 2.5)$ & $19.7-26.4$ \\
\hline \multirow[t]{3}{*}{ Klipdrift } & Raw water source & $18.5( \pm 15.0)$ & $4.66-76.7$ & $9.0( \pm 0.4)$ & $8-9.81$ & $23.6( \pm 2.1)$ & $20-28.6$ \\
\hline & Sedimentation & $16.8( \pm 13.3)$ & $4.55-60.6$ & $8.8( \pm 0.5)$ & $8.11-9.78$ & $23.3( \pm 2.2)$ & $18.5-26.1$ \\
\hline & Filtration & $1.1( \pm 0.4)$ & $0.34-1.88$ & $8.8( \pm 0.6)$ & $8-9.62$ & $23.1( \pm 2.2)$ & $18.6-26$ \\
\hline \multirow[t]{3}{*}{ Wallmansthal } & Raw water source & $11.9( \pm 7.3)$ & $3.51-25.4$ & $8.4( \pm 0.5)$ & $7.9-9.54$ & $22.5( \pm 1.7)$ & $19.2-24.9$ \\
\hline & Sedimentation & $2.8( \pm 1.4)$ & $0.69-6$ & $8.3( \pm 0.3)$ & $7.71-8.98$ & $23.4( \pm 2.8)$ & $18.2-26.6$ \\
\hline & Filtration & $0.5( \pm 0.2)$ & $0.05-0.94$ & $8.3( \pm 0.3)$ & $7.85-8.9$ & $22.2( \pm 1.7)$ & $18.3-25.2$ \\
\hline
\end{tabular}

Recommended limits: Turbidity: $\leq 5 \mathrm{NTU}$ after coagulation/flocculation, $\leq 1 \mathrm{NTU}$ after filtration, $\mathrm{pH}-6-9$, Temperature $\leq 25^{\circ} \mathrm{C}(\mathrm{DWAF} 1996$; WHO 2004a). Numbers in brackets: Standard deviation

values in water samples collected from Temba (0.4 NTU) and Wallmansthal (0.5 NTU) were below the recommended limit and that of Klipdrift (1.1 NTU) was slightly above the limit, which is 1 NTU (Table 2). Turbid water increases the chances of transmission of disease by microorganisms associated with particulate matter such as viral or parasitic pathogens, which are known for their low infective dose. This could, in the long run, lead to the reduced effectiveness of a plant's disinfection process (Mann et al. 2007). There is an evident need for continual optimisation of these processes, particularly at the Temba and Klipdrift WTPs. This would result in a substantial reduction in turbidity at each stage.

The effectiveness of virus removal during water treatment may also be affected by factors that act against particle association (floc formation), such as $\mathrm{pH}$ and temperature conditions (Grabow 2001; LeChevelier and $\mathrm{Au}$ 2004). Although, on average, the $\mathrm{pH}$ values recorded were within the recommended limits $(\mathrm{pH}$ 6-9), there were maximum values of 9.50 and 9.78 in settled water and of 9.41 and 9.62 in water samples collected after filtration from Temba and Klipdrift, respectively. These values were above the recommended limits (Table 2). An ideal $\mathrm{pH}$ ranging from 6 to 9 in water is essential for chemical reactions, for instance, the process of coagulation (SANS: $241,2006)$, which promotes particle association.

The average temperature values for raw, settled and filtered water fell within the recommended limit $\left(\leq 25{ }^{\circ} \mathrm{C}\right)$ for the three water treatment plants. The temperature values from Temba after filtration were higher than those from Wallmansthal. The Temba $\left(27.8{ }^{\circ} \mathrm{C}\right)$, Klipdrift $\left(26.1^{\circ} \mathrm{C}\right)$ and Wallmansthal $\left(26.6{ }^{\circ} \mathrm{C}\right)$ water had maximum temperature values above the recommended limit before filtration. After filtration, almost similar maximum temperatures were found in both the Temba $\left(26.4{ }^{\circ} \mathrm{C}\right)$ and Klipdrift $\left(26^{\circ} \mathrm{C}\right)$ samples, with the maximum temperature values above the limit (Table 2). Maintaining a temperature of $\leq 25^{\circ} \mathrm{C}$ in accordance with the recommended standards (SANS: 241, 2006) is essential not only for the efficacy of the physicochemical reactions and preventing the toxicity of metals that most could possibly be found in the water (USEPA 1999, 2001; Momba et al. 2006a), but also for promoting the inactivation of viruses in water (Grabow 2001; Cole et al. 2003; Duran et al. 2002). Collectively, virus removal and inactivation may be effectively achieved by increased temperatures and extremes of $\mathrm{pH}$ (Sinton et al. 1999; Feng et al. 2003).

Performance of the plants in the removal of somatic and FRNA coliphages

Table 3 and Fig. 1 illustrate the performance of the Temba, Klipdrift and Wallmansthal WTPs in the removal of somatic and FRNA coliphages during the pre-treatment processes. The study revealed a reduction in both somatic and FRNA-specific coliphages throughout the treatment processes of the three Waterworks. The percentage removal of somatic coliphages ranged from 25.5 to $72.9 \%$ after sedimentation and from 93.2 to $96.1 \%$ after filtration (Table 3). The highest percentage removal, on average, was recorded at the Wallmansthal WTP after sedimentation (72.9 \%), and Klipdrift revealed a $96.1 \%$ somatic coliform removal after filtration. Compared to the other two plants, the somatic coliphage counts at the Temba WTP were notably higher; a maximum value of $25 \mathrm{pfu} / 10 \mathrm{~mL}$ was noted during the study period (Table 3 ). Although the Wallmansthal WTP had the lowest recorded FRNA coliphage counts from the raw water samples and $100 \%$ removal after sedimentation, there was a reoccurrence of FRNA coliphages after filtration (50\%). Compared to the 
other plants, the Temba WTP had the highest FRNA coliphage counts in raw water and settled water (Table 3; Fig. 1). Average percentage removals of 52 to $100 \%$ after sedimentation and of 68.4 to $69.4 \%$ after filtration were recorded during the study period (Table 3 ). In the overall investigation, somatic coliphage counts were found to be significantly higher than FRNA coliphage counts. Similar findings were also reported by Momba et al. (2006b) when these authors conducted a study on the impact of inadequate wastewater treatment of the receiving water bodies. The removal of viruses in water that is meant for human consumption is important, as many viral disease outbreaks worldwide occur as a result of the intake of water that contains viruses, even at low levels ( $\geq 10 / \mathrm{L}$ ) (WHO 2004a). Somatic and FRNA coliphages were selected because they have been proposed as indicators for the presence of enteric viruses in water sources (Debartolomeis and Cabelli 1991; Havelaar et al. 1993). Diseases caused by enteric viruses, especially of human origin, are considered to be predominantly associated with the ingestion of human-derived waste because of their host-specificity (Sundram et al. 2002).

Correlation between the removal of coliphages and the physicochemical characteristics of the water samples after pre-treatment

The relationship between the physicochemical parameters and coliphage removal, although not significant $(p>0.05)$ in most instances, was notable. Statistically, this means that these relations were not as significant as might have been expected, although inverse relations were registered in a number of cases (Table 4). However, it is evident that the efficient removal of somatic coliphages from intake water sources through coagulation/flocculation, sedimentation and filtration processes was related to the reduction in turbidity in the water up to the recommended limits (i.e. 5 NTU after sedimentation and 1 NTU after filtration) and also to the optimal $\mathrm{pH}$ and temperature values that were in accordance with the limits (Grabow 2001; LeChevelier and Au 2004). After sedimentation, the somatic coliphage counts were observed to have negative correlations with the physicochemical parameters (NTU, pH and temperature) from Temba and Wallmansthal, while, after filtration, positive correlations were observed from both Temba and Klipdrift (Table 4). Although, in some instances, the analysed physicochemical parameters in this study played a role in the removal of FRNA coliphages from the water, this group of viral indicators has been reported to be more resistant to environmental conditions (Grabow 2001; Feng et al. 2003). This could clearly explain the $50 \%$ reoccurrence of the FRNA coliphages in filtered water from the Wallmansthal Waterworks (Table 4). According to Feng et al. (2003), the inactivation of FRNA coliphages has been reported to increase when the $\mathrm{pH}$ decreased to below 6 or increased above 8 and with the increment of temperature (Feng et al. 2003). The effectiveness of coagulation, flocculation, sedimentation and filtration processes to remove viruses in water has been indicated to range roughly from 1 to $3 \log$ (WHO 2004b). It is apparent that, in order to have an optimal viral removal or viral reduction during water treatment, the optimisation of these processes is of paramount importance, that is, monitoring coagulation dose rates, appropriate chemical mixing, etc. This will promote the efficiency of the removal of particulate matter associated with viruses in water (LeChevelier and $\mathrm{Au}$ 2004).

Table 3 Summary of the performance of WTPs in the removal of somatic and FRNA coliphages: indicating the average counts (pfu/10 mL) and percentage viral removal after filtration

\begin{tabular}{|c|c|c|c|c|c|c|c|c|}
\hline WTP & $\begin{array}{l}\text { Raw water } \\
\text { source } \\
\text { pfu/10 mL }\end{array}$ & $\begin{array}{l}\text { Min-max } \\
\text { pfu/10 m } \ell\end{array}$ & $\begin{array}{l}\text { Settled } \\
\text { pfu/10 mL }\end{array}$ & $\begin{array}{l}\text { Min-max } \\
\text { pfu/10 mL }\end{array}$ & $\begin{array}{l}\% \\
\text { Removal }\end{array}$ & $\begin{array}{l}\text { Filtered } \\
\text { pfu/10 mL }\end{array}$ & $\begin{array}{l}\text { Min-max } \\
\text { pfu/10 mL }\end{array}$ & $\begin{array}{l}\% \\
\text { Removal }\end{array}$ \\
\hline \multicolumn{9}{|c|}{ Somatic (average counts) } \\
\hline Temba & 66 & $10-170$ & 34 & $15-115$ & 48.5 & 2.3 & $0-25$ & 93.2 \\
\hline Klipdrift & 31 & $10-100$ & 23.1 & $0-125$ & 25.5 & 0.9 & $0-5$ & 96.1 \\
\hline Wallmansthal & 34 & $0-100$ & 9.2 & $0-45$ & 72.9 & 0.4 & $0-5$ & 95.7 \\
\hline \multicolumn{9}{|c|}{$F-R N A$ (average counts) } \\
\hline Temba & 10.2 & $0-80$ & 4.9 & $0-65$ & 52 & 1.5 & $0-5$ & 69.4 \\
\hline Klipdrift & 9.5 & $0-35$ & 1.9 & $0-20$ & 80 & 0.6 & $0-5$ & 68.4 \\
\hline Wallmansthal & 0.4 & $0-10$ & 0 & 0 & 100 & 0.2 & $0-5$ & $\begin{array}{l}50 \\
\text { (reoccurrence) }\end{array}$ \\
\hline
\end{tabular}

Max-min maximum and minimum, $\%$ percentage 
Table 4 Correlation between coliphage counts and physicochemical parameters

\begin{tabular}{|c|c|c|c|c|c|c|c|c|c|c|c|c|}
\hline \multirow[t]{3}{*}{ Parameters } & \multicolumn{6}{|c|}{ Sedimentation (settled) } & \multicolumn{6}{|l|}{ Filtered } \\
\hline & \multicolumn{2}{|l|}{ Temba } & \multicolumn{2}{|c|}{ Klipdrift } & \multicolumn{2}{|c|}{ Wallmansthal } & \multicolumn{2}{|l|}{ Temba } & \multicolumn{2}{|c|}{ Klipdrift } & \multicolumn{2}{|c|}{ Wallmansthal } \\
\hline & $\mathrm{r}$ & $p$ & $\mathrm{R}$ & $p$ & $\mathrm{R}$ & $p$ & $\mathrm{r}$ & $p$ & $\mathrm{r}$ & $p$ & $\mathrm{r}$ & $p$ \\
\hline \multicolumn{13}{|c|}{ Somatic coliphages } \\
\hline NTU & -0.12 & 0.58 & 0.14 & 0.5 & -0.12 & 0.58 & 0.03 & 0.88 & 0.13 & 0.56 & 0.005 & 0.98 \\
\hline $\mathrm{pH}$ & -0.21 & 0.32 & 0.11 & 0.62 & -0.03 & 0.89 & 0.1 & 0.64 & 0.04 & 0.87 & -0.37 & 0.08 \\
\hline $\mathrm{T}\left({ }^{\circ} \mathrm{C}\right)$ & -0.13 & 0.53 & 0.01 & 0.96 & -0.18 & 0.4 & 0.11 & 0.61 & 0.24 & 0.25 & -0.11 & 0.62 \\
\hline \multicolumn{13}{|c|}{ F-RNA coliphages } \\
\hline NTU & -0.06 & 0.79 & 0.75 & 0.0 & $*$ & 0.0 & 0.3 & 0.16 & 0.31 & 0.14 & -0.02 & 0.91 \\
\hline $\mathrm{pH}$ & 0.04 & 0.84 & -0.15 & 0.5 & $*$ & 0.0 & -0.06 & 0.77 & -0.06 & 0.76 & -0.002 & 0.99 \\
\hline $\mathrm{T}\left({ }^{\circ} \mathrm{C}\right)$ & 0.15 & 0.47 & 0.28 & 0.18 & $*$ & 0.0 & 0.1 & 0.66 & 0.04 & 0.84 & -0.29 & 0.18 \\
\hline
\end{tabular}

$r$, correlation, $p \leq 0.05 ; \mathrm{T}\left({ }^{\circ} \mathrm{C}\right)$, temperature; NTU, turbidity; $*=$ No F-RNA coliphage counts in settled water

Table 5 RT Identification of randomly selected samples

\begin{tabular}{lllll}
\hline Percentage occurrence of F-RNA & & \\
\hline Plant & $\begin{array}{l}\text { Water } \\
\text { source }\end{array}$ & $\begin{array}{l}\text { Group 1 (MS2 Genotype)- } \\
\text { Predominantly animal faecal } \\
\text { contamination }\end{array}$ & $\begin{array}{l}\text { Group 2 (GA Genotype)- } \\
\text { Predominantly human faecal } \\
\text { contamination }\end{array}$ & $\begin{array}{l}\text { Group 3 (Q } \beta \text { Genotype)- } \\
\text { Predominantly human faecal } \\
\text { contamination }\end{array}$ \\
\hline Temba & Raw & $1 / 8(12.5 \%)$ & $1 / 8(12.5 \%)$ & $2 / 8(25 \%)$ \\
& Sediment & $0 / 8$ & $3 / 8(37.5 \%)$ & $0 / 8$ \\
& Filtered & $0 / 8$ & $3 / 8(37.5 \%)$ & $0 / 8$ \\
Klipdrift & Raw & $0 / 8$ & $2 / 8(25 \%)$ & $0 / 8$ \\
& Sediment & $0 / 8$ & $2 / 8(25 \%)$ & $0 / 8$ \\
& Filtered & $0 / 8$ & $3 / 8(37.5 \%)$ & $0 / 8$ \\
Wallmansthal & Raw & $0 / 8$ & $5 / 8(62.5 \%)$ & $0 / 8$ \\
& Sediment & $0 / 8$ & $3 / 8(37.5 \%)$ & $0 / 8$ \\
& Filtered & $0 / 8$ & $3 / 8(37.5 \%)$ & $0 / 8$
\end{tabular}

\section{Genotyping of F-RNA}

Observations made after direct genotyping of FRNA coliphages found in water samples collected from the three WTPs revealed the persistent predominance of GA genotype FRNA (Group II), with the exception of raw water from the Temba WTP, where MS2 genotype FRNA (Group I) and $\mathrm{Q} \beta$ genotype FRNA (Group III) were also detected (Table 5). These three genotypes were readily detectable by RT-PCR, which is a more sensitive method, even in samples in which FRNA coliphages were not detected using the direct conventional method. They have been reported to be predominantly associated with animal (Group I) and human faecal contamination (Group II and Group III) (Sundram et al. 2002).

Of the selected eight raw water samples collected from Temba WTP, one sample $(12.5 \%)$ contained MS2 genotype FRNA (Group I), another sample $(12.5 \%)$ contained
GA genotype FRNA (Group II) and two samples (25\%) contained $\mathrm{Q} \beta$ genotype FRNA (Group III). After sedimentation and filtration, only GA genotype FRNA was identified in the water samples. Three (37.5\%) out of eight water samples collected from these points of treatment barriers were positive for this genotype group (Table 5). For the Klipdrift WTP, only GA genotype FRNA (Group II) was identified from raw, settled and filtered water samples. Of the eight water samples analysed from each point, two $(25 \%)$, two $(25 \%)$ and three $(37.5 \%)$ samples were positive for this genotype (Table 5). For the Wallmansthal WTP, of the eight water samples that were analysed from each critical sampling point (raw, sedimentation and filtration), five $(62.5 \%)$, three $(37.5 \%)$ and three (37.5) of the samples were positive for GA genotype F-RNA (Group II) (Table 5).

Results of this study revealed that animal and human faeces served as sources of faecal contamination for the 
intake water sources used by the Temba WTP, while water sources entering the Klipdrift and Wallmansthal WTPs revealed human faecal contamination. The results also indicated the sources of pollution of the raw water source and the persistence of FRNA coliphage genotypes during water treatment. These results agree with the findings by previous investigators, who also pointed out the resistance of enteric viruses to water treatment processes (Grabow et al. 2001; Tree et al. 2003). They confirm the results of previous studies (Ogorzaly and Gantzer 2006; Ogorzaly et al. 2010), which concluded that FRNA phages can be used as a special tool to provide information on sources of faecal pollution in water sources.

\section{Conclusion}

Pathogenic viruses in water sources are a significant public health risk; therefore, their resistance to water treatment is of great concern in terms of their apparent outbreaks of waterborne diseases. This concern is exacerbated by the inability to conduct a monitoring programme for important viral pathogens.

The present study indicates that no single treatment barrier can be expected to remove all the different types of viral indicators that can be found in water under various conditions. To enhance the removal of viral indicators, each drinking water treatment plant should be optimised regularly. The study also points out the importance of a drinking water monitoring programme, which possibly will contribute to the control of organisms causing waterborne disease outbreaks in communities. For an effective management of water treatment plants to produce safe drinking water, this study recommends the use of FRNA coliphages to determine the origin of faecal contamination in each treatment barrier. The study therefore suggests that water service providers, especially in developing countries, should include in their water safety plans a water monitoring programme for viral indicators such as FRNA coliphages to trace the source of pollution for the sake of water source management.

Acknowledgments The authors would like to thank the National Research Foundation and the Tshwane University of Technology for funding and supporting this project, and Dr. E. Madoroba for assisting with the molecular part of the study.

\section{References}

APHA (2001) Standard methods for the examination of water and wastewater, 20th edn. American Public Health Association, American Water Work Association, Water Environment Federation, Washington, DC, USA
Calci KR, Burkhardt W III, Watkins WD, Rippey SR (1998) Occurrence of male-specific bacteriophage in feral and domestic animal wastes, human feces, and human-associated wastewaters. Appl Environ Microbiol 64:5027-5029

Cole D, Long SC, Sobsey MD (2003) Evaluation of F-RNA and DNA coliphages as source-specific indicators of fecal contamination in surface waters. Appl Environ Microbiol 69:6507-6514

Debartolomeis J, Cabelli VJ (1991) Evaluation of an Escherichia coli host strain for enumeration of $\mathrm{F}$ malespecific bacteriophages. Appl Environ Microbial 57:1301-1305

Department of Water Affairs and Forestry (DWAF) (1996) South African Water Quality Guidelines for domestic water use (2nd edition). Pretoria, South Africa, pp 83-87

Dryden SK, Ramaswami B, Yuan Z, Giammar DE, Angenent LT (2006) A rapid reverse transcription-PCR assay for F + RNA coliphages to trace fecal pollution in Table Rock Lake on the Arkansas-Missouri border. Water Res 40:3719-3724

Duran AE, Muniesa M, Mendez X, Valero F, Lucena F, Jofre J (2002) Removal and inactivation of indicator bacteriophages in fresh waters. J Appl Microbiol 92:338-347

Feng YY, Ong SL, Hu JY, Tan XL, Ng WJ (2003) Effects of pH and temperature on the survival of coliphages MS2 and Q $\beta$. J Ind Microbiol Biotechnol 30(374):549-552

Fong TT, Lipp EK (2005) Enteric viruses of humans and animals in aquatic environments: health risks, detection, and potential water quality assessment tools. Microbiol Mol Biol Rev 69:357-371

Grabow WOK (2001) Bacteriophages: update on application as models for viruses in water. Water SA 27:251-268

Grabow WO, Taylor MB, de Villiers JC (2001) New methods for the detection of viruses: call for review of drinking water quality guidelines. Water Sci Technol 43(12):1-8

Greening G, Hewitt J, Lewis G (2002) Evaluation of integrated cell culture-PCR (C-PCR) for virological analysis of environmental samples. J Appl Microbiol 93:745-750

Havelaar AH, Pot-Hogeboom WM, Furuse L, Pot R, Hormann MP (1990) F-specific RNA bacteriophages and sensitive host strains in faeces and wastewater of human and animal origin. $\mathrm{J}$ Appl Bacteriol 69:30-37

Havelaar AH, Van Olphen M, Drost YC (1993) F-specific RNA bacteriophages are adequate model organisms for enteric viruses in fresh water. Appl Environ Microbiol 59:2956-2962

ISO (1995) Water quality-Detection and enumeration of bacteriophages. Part 1: enumeration of F-specific RNA bacteriophages. International Organization for Standardization: Geneva. ISO 10705-1:1995, $15 \mathrm{pp}$

ISO (1998) Water quality-Detection and enumeration of bacteriophages. Part 2: Enumeration of Somatic Coliphages. International Organization for Standardization: Geneva. ISO/DIS 10705-2.2. 1995, $17 \mathrm{pp}$

LeChevelier M, Au KK (2004) Water treatment and pathogen control: process efficiency in achieving safe drinking-water. WHO drinking-water quality series. WHO, Geneva. Available from: http://www.who.int/water_sanitation_health/dwq/9241562552/ en/index.html. Accessed 09 Dec 2009

Lee HK, Jeong YS (2004) Comparison of total culturable virus assay and multiplex integrated cell culture-PCR for reliability of waterborne virus detection. Appl Environ Microbiol 70: 3632-3636

Lewis GD, Molloy SL, Greening GE, Dawson J (2000) Influence of environmental factors on virus detection by RT-PCR and cell culture. J Appl Microbiol 88:633-640

Lugoli F, Leopizzi MI, De Donno A (2009) Viral indicators of hygienic-sanitary quality: detection of somatic coliphages in the Southern Adriatic Sea. Available from: http://www.springerlink. com/content/n07n101547246710/fulltext.pdf. Accessed 09 Dec 2009 
Mann AG, Tam CC, Higgins CD, Rodrigues LC (2007) The association between drinking water turbidity and gastrointestinal illness: a systematic review. BMC Public Health., 7, 256. Available from: http://www.ncbi.nlm.nih.gov/pmc/articles/PMC 2174477/pdf/1471-2458-7-256.pdf. Accessed 21 Jan 2010

Momba MNB, Tyafa Z, Makala N, Brouckaert BM, Obi CL (2006a) Safe drinking water still a dream in rural areas of South Africa. Case Study: The Eastern Cape Province. Water SA 32:715-720

Momba MNB, Osode AN, Sibewu M (2006b) The impact of inadequate wastewater treatment on the receiving water bodies-Case study: Buffalo City and Nkonkobe Municipalities of the Eastern Cape. Water SA 32(5):687-692

Ogorzaly L, Gantzer C (2006) Development of real-time RT-PCR methods for specific detection of F-specific RNA bacteriophage genogroups: application to urban raw wastewater. J Virol Methods 138:131-139

Ogorzaly L, Bertrand I, Paris M, Maul A, Gantzer C (2010) Occurrence, survival, and persistence of human adenoviruses and F-Specific RNA phages in raw groundwater. Appl Environ Microbiol 76(24):8019-8025

SANS: 241 (2006) South African National Standard 241: Drinking Water Standards, 6th edn. Pretoria, South Africa

Sinton LW, Finlay RK, Lynch PA (1999) Sunlight inactivation of fecal bacteriophages and bacteria in sewage-polluted seawater. Appl Environ Microbiol 65:3605-3613

Sobsey MD (1989) Inactivation of health-related microorganisms in water by disinfection processes. Water Sci Technol 21:179-195

Sundram A, Donnelly L, Ehlers MM, Vrey A, Grabow WOK, Bailey IW. (2002) Evaluation of FRNA as indicators of viruses and source of faecal pollution. Water SA special edition WISA proceedings. Available from: http://www.wrc.org.za/Knowled ge\%20Hub\%20Documents/Water\%20SA\%20Journals/Manuscripts/ 2002/05/WaterSA_2002_05_18.pdf. Accessed 09 Dec 2009

Tree JA, Adams MR, Lees DN (2003) Chlorination of indicator bacteria and viruses in primary sewage effluent. Appl Environ Microbiol 69(4):2038-2043

USEPA (1999) Guidance manual for alternative disinfectants and oxidants. Washington, DC, USA. HDR Inc., Available from: http:// www.epa.gov/safewater/mdbp/mdbptg.html\#disinfect. Accessed 20 Oct 2008

USEPA (2001) Manual of methods for virology. Washington, DC, USA. Available from: http://www.epa.gov/microbes/chapt16. pdf. Accessed 09 Dec 2009

WHO (2004a) Guidelines for drinking-water quality, 3rd edn. Vol 1: recommendations. World Health Organisation, Geneva

WHO (2004b) Water treatment and pathogen control: process efficiency in achieving safe drinking water. Edited by Mark W. LeChevallier and Kwok-Keung Au. Published by IWA Publishing, London, UK. ISBN: 184339069 8. Available from: http://www.who.int/ water_sanitation_health/dwq/en/watreatpath2.pdf. Accessed 10 May 2010

WHO (2006) Guidelines for drinking-water quality, 3rd edn, incorporating first and second addendum to third edition (Vol. 1). IWA Publication, pp 48-83. Available from: http://www.who. int/water_sanitation_health/dwq/GDW4revrev1and2.pdf. Accessed 09 Dec 2009 